\title{
THE EFFECT OF ACLARUBICIN (ACL) ON HUMAN ERYTHROCYTES
}

\author{
PIOTR WITCZAK, AGNIESZKA MARCZAK
}

\author{
Department of Thermobiology, University of Lodz, Pomorska 141/143, 90-236 Lodz, Poland, email: aszwar@ biol.uni.lodz.pl
}

Received December 15, 2010; accepted May 30, 2011; published online June 02, 2011

\begin{abstract}
The present study examines the influence of aclarubicin (ACL) on human red blood cells with a focus on the generation of reactive oxygen species (ROS). A statistically significant increase in ROS levels was observed for all the tested concentrations of aclarubicin $(1-20 \mathrm{nM})$. The depletion of catalase activity and elevated metHb content were also observed. On the other hand, changes in reduced glutathione (GSH) and total glutathione concentrations were not statistically significant. The presented results confirm important role of ROS in ACL cytotoxic activity.
\end{abstract}

\section{INTRODUCTION}

Anthracyclines are the most commonly administered anticancer drugs used to treat solid tumors and leukemias. Their wide range of application and great efficacy notwithstanding, they are highly toxic to normal cells. Researchers are trying to modify the chemical structures of anthracyclines to obtain more effective and less toxic derivatives. One of these is aclarubicin (ACL), which is a second-generation anthracycline antibiotic. Isolated in 1975 from the Streptomyces galileus strain (Chmiel \& Grudziński 1998), ACL is administered intravenously or orally and is transported from blood to tissues (Rogalska, Marczak \& Jóźwiak 2008). This drug is frequently applied in the treatment of patients resistant to doxorubicin and daunorubicin (first generation anthracyclines). The cytotoxic effect of ACL results from DNA intercalation and perturbations in the function and structure of cell and mitochondrial membranes (Chenais, Andriollo, Guiraud, Belhoussine \& Jeannesson 2000). Unlike DOX or DNR, ACL interacts with topoisomerase II and also inhibits topoisomerase I (Hajji, Mateos, Pastor, Dominguez \& Cortes 2005). ACL is one of the newer N,N dimethylated trisaccharide anthracyclines containing aclavinone aglycone. The saccharic residue comprises three pentoses: L-rhodosamine, 2-deoxy-L-fucose, $\alpha$ cinerulose, and it is linked to aglycone with the oglycoside bond (Fig. 1). ACL is considered less cardiotoxic and its cytotoxic mechanisms differ from those of first-generation anthracyclines.

We investigated ACL cytotoxic activity related to ROS generation. The quinone structure present in anthracycline molecules easily undergoes one-electron reduction to a semiquinone radical (Fig. 2).
Subsequently, an electron is transferred to intracellular molecular oxygen, which leads to the formation of an anion superoxide $\left(\mathrm{O}_{2}^{-}\right)$. At the same time, the semiquinone ring is regenerated to the primary quinone form. This process, catalyzed by flavoproteins, is responsible for electron transfer from NADPH or NADH. The presence of $\mathrm{O}_{2}^{-}$causes cascade reactions resulting in the synthesis of $\mathrm{H}_{2} \mathrm{O}_{2}$ and the highly reactive hydroxide radical $(\mathrm{OH})$. Nonenzymatic generation of free radicals is possible as well (Zweier, Gianni, Muindi $\&$ Myers, 1986).

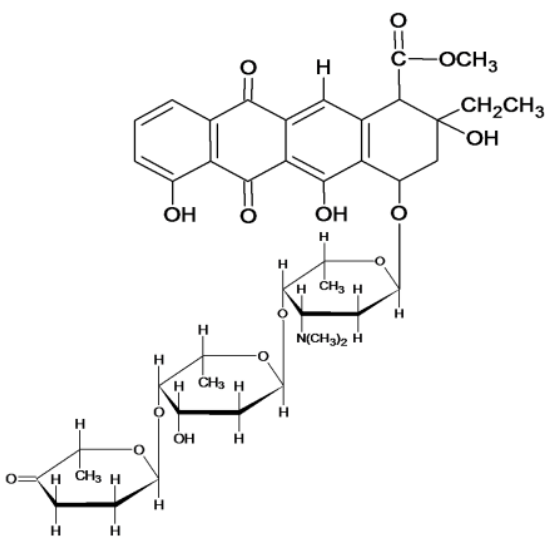

Fig. 1. Chemical structure of aclarubicin

ROS react with all cellular components, contributing to lipid peroxidation, DNA and protein impairments (Oliński \& Jurgowiak 1999, Szuławska \& Czyż 2006, Łubgan, Marczak, Walczak, Distel \& Jóźwiak 2006, Dudka 2006), and apoptosis or necrosis induction (Kania, Zych \& Jóźwiak 2007; Rogalska, Koceva-Chyła \& Jóźwiak 2008). 


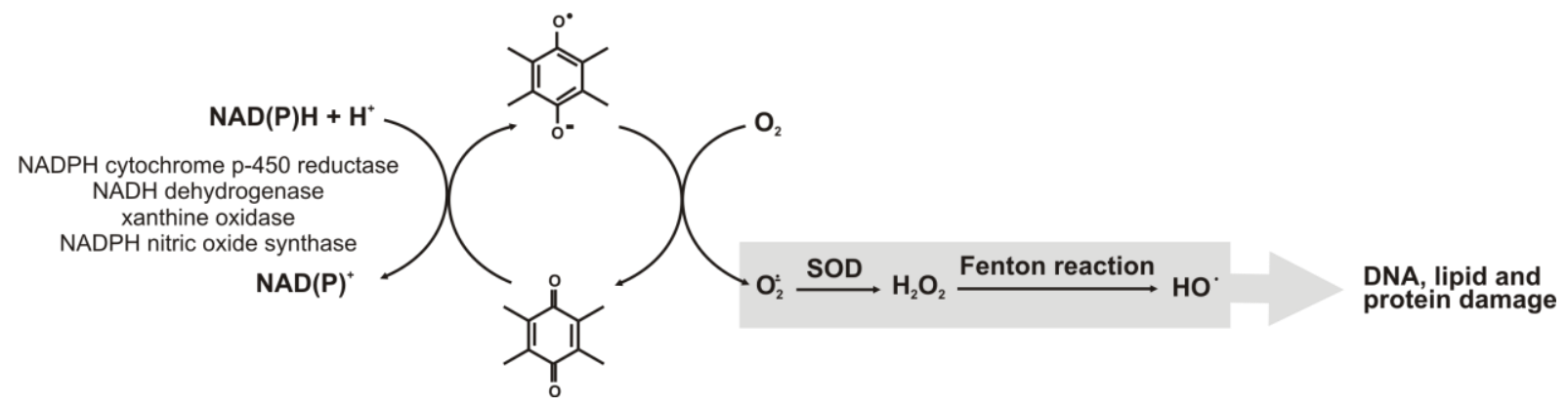

Fig. 2 ROS generation in one electron reduction of anthracyclines (according to Dudka, 2006).

The aim of this study was to determine the effect of aclarubicin on red blood cells. Therefore, selected parameters of these cells preincubated with the investigated drug were analyzed: reactive oxygen species levels, catalase activity, methemoglobin content and the concentration of reduced and total glutathione.

\section{MATERIALS AND METHODS}

Preparation of erythrocyte suspension and treatment of erythrocytes with drug

Human peripheral blood from healthy donors in ACD (23 mM citric acid; $45.1 \mathrm{mM}$ sodium citrate; $45 \mathrm{mM}$ glucose) solution was centrifuged at $600 \times \mathrm{g}$ for 10 minutes. After plasma and buffy coat removed, erythrocytes were washed three times in phosphate buffered saline, PBS, ( $5 \mathrm{mM}$ sodium phosphate buffer, containing $0.15 \mathrm{M} \mathrm{NaCl}, \mathrm{pH} 7.4)$ and then suspended in the same medium. Erythrocyte suspensions (5\% hematocrit) in PBS were incubated with aclarubicin at a final concentration of $1-20 \mathrm{nM}$ in the dark for $60 \mathrm{~min}$ in a shaking bath at $37^{\circ} \mathrm{C}$.

\section{Drug content in extracellular medium}

The level of ACL in the medium was determined by absorbance measurements of the supernatant at $\lambda=$ $430 \mathrm{~nm}$ after centrifugation the red blood cells at $600 \times \mathrm{g}$ for 10 minutes. Indications were conducted with the wave length assigned from absorption spectrum drawn in $400-600 \mathrm{~nm}$. Maximum was indicated for $\lambda=$ $430 \mathrm{~nm}$. The sample centrifuged immediately after drug treatment was used as the control, and its absorbance was assumed as $100 \%$.

\section{ROS level}

To measure the production of ROS, erythrocyte suspension in PBS $(\mathrm{H}=0.1 \%)$ was treated with a fluorescence probe, 6-carboxy-2',7'-dichloro-dihydrofluorescein diacetate (C-DCDHF-DA), for $30 \mathrm{~min}$ in the dark. The final concentration of C-DCDHF-DA was $20 \mu \mathrm{M}$. The probe diffuses across the cell membrane and is hydrolyzed by intracellular esterases to C-DCDHF, which, upon oxidation, yields the highly fluorescent dichlorofluorescein (DCF). Fluorescence was measured in 30000 cells by using a Becton Dickinson LSR II flow cytometer with excitation of $488 \mathrm{~nm}$ (blue laser) and a $530 \mathrm{~nm}$ emission filter; single-parameter histograms were set for the fluorescence signal of DCF, measured in channel F1 (Grasso, Scifo, Cardile, Gulino \& Renis 2003, Richard, Hollender \& Chénais 2002).

\section{Catalase activity}

Catalase activity was estimated with the Aebi spectrofotometric method (Aebi 1984) based on measurement of hydrogen peroxide decomposition velocity as a substrate of this enzyme. Phosphate buffer of $50 \mathrm{mM}$ concentration and $\mathrm{pH} 7.0$ was stirred with $54 \mathrm{nM}$ water solution of hydrogen peroxide in volume proportion $2: 1$. To initiate the resolution reaction of hydrogen peroxide, hemolysate containing catalase was added and the measurement of absorbance decrease was conducted for 3 minutes at $\lambda=240 \mathrm{~nm}$ (hydrogen peroxide maximum) and in reference to phosphate buffer. One unit of catalase activity was defined as the activity required to degrade $1 \mu \mathrm{mol}$ of hydrogen peroxide in $1 \mathrm{~min}$, at $\mathrm{pH} 7$ and $25^{\circ} \mathrm{C}$. It is the equivalent of 0.0145 absorbance unit decrease within 1 minute. The final result was expressed as micromoles of $\mathrm{H}_{2} \mathrm{O}_{2}$ reduced per minute per milligramme of $\mathrm{Hb}$. $\mathrm{Hb}$ concentration was assessed by the Drabkin method (Kłyszejko-Stefanowicz 2003).

$$
U / \mathrm{mg} H b\left[\mu \mathrm{mol} \cdot \min ^{-1} \cdot \operatorname{mg} H b^{-1}\right]=\Delta A_{240} / \mu \varepsilon \cdot l \cdot t
$$

where:

$U$ - enzyme activity,

$\Delta A_{240}$ - absorbance decrease in investigated sample, $\mu \varepsilon-$ micromolar absorption coefficient for hydrogen peroxide $\left[\mu \mathrm{M}^{-1} \mathrm{~cm}^{-1}\right]$,

$l$ - length of optical way $[\mathrm{cm}]$,

$t$-time [min]. 


\section{Methemoglobin content}

Analysis of the level of oxidized hemoglobin $(\mathrm{metHb})$ in erythrocytes was estimated by measurement of absorbance of hemolysates at 630 and $700 \mathrm{~nm}$ and compared with that of hemolysates treated with excess ferricyanide. Percentage content of hemoglobin in samples incubated with ACL was calculated according to the formula:

$$
\% \text { met } H b=\frac{100 \times\left(A_{630}-A_{700}\right)}{A_{100 \% \text { met } H b 630}-A_{100 \% \text { metHb700 }}}
$$

where:

$A_{630}$ - absorbance of the investigated sample at $630 \mathrm{~nm}$ without ferricyanide potassium,

$A_{700}$ - absorbance of the investigated sample at $700 \mathrm{~nm}$ without ferricyanide potassium,

$A_{100 \% \text { metHb630 }}{ }^{-}$absorbance of the investigated sample at $630 \mathrm{~nm}$ with ferricyanide potassium,

$A_{100 \% \text { metHb700 - absorbance of the investigated sample at }}$ $700 \mathrm{~nm}$ with ferricyanide potassium.

\section{Reduced and total glutathione measurement}

The level of reduced glutathione (GSH) in erythrocytes was determined by the method of Ellman (1959). Erythrocyte suspension was deproteinated by addition of trichloroacetic acid (TCA) to a final concentration of $2 \%$. To the supernatant (with glutathione) cleared by centrifugation, 5,5-dithio-bis(2nitrobenzoic acid) (DTNB) was added to a final concentration of $0.47 \mathrm{mM}$. The formation of 5-thio-2nitrobenzoic acid, which is proportional to the concentration of acid soluble thiols mainly gluthatione, was monitored at $25{ }^{\circ} \mathrm{C}$. The absorbance was measured at $412 \mathrm{~nm}$ in a Varian Cary 50 spectrophotometer (Carl Zeiss, Jena, Germany) against a reagent blank. The concentrations of reduced glutathione in samples were calculated from a standard curve of absorbance versus concentration of glutathione and expressed as micromol per milliliter packed cells.

Total glutathione was measured according to the method of Akerboom \& Sies (1981). The method is based on the catalytic action of glutathione reductase in a system, in which GSH undergoes sequential oxidation by DTNB and reduction by NADPH. The measure of the concentration of glutathione in samples is the velocity of increase of absorbance. To erythrocytes of $5 \%$ hematocrit the solution of $2 \mathrm{M} \mathrm{HClO}_{4}$ containing $4 \mathrm{mM}$ EDTA was added, the sample was quickly mixed and centrifuged $(600 \mathrm{~g} \times 10 \mathrm{~min})$, and the supernatant was collected. Before determination, a known volume of the supernatant was neutralized using $0.3 \mathrm{M} \mathrm{N}$ morpholinepropanosulphonic acid (MOPS) diluted in $2 \mathrm{M} \mathrm{KOH}$. To a spectrophotometric cuvete the following reagents were added: $1000 \mu \mathrm{l}$ of $0.1 \mathrm{M}$ phosphate buffer containing $1 \mathrm{mM}$ EDTA, $\mathrm{pH}=7,100 \mu \mathrm{l}$ of supernatant containing $0.5-2 \mathrm{mM}$ glutathione, $50 \mu \mathrm{l}$ of NADPH solution $(4 \mathrm{mg} / \mathrm{ml}$ in $0.5 \% \mathrm{NaHCO} 3), 20 \mu 1$ 5,5-dithioBis-2-nitrobenzoic acid (DTNB $5 \mathrm{mg} / \mathrm{ml}$ in $0.5 \%$ $\mathrm{NaHCO} 3)$ and $20 \mu \mathrm{l}$ of glutathione reductase solution (6 $\mathrm{U} / \mathrm{ml})$. After mixing, the absorbance was measured at $412 \mathrm{~nm}$ for $3 \mathrm{~min}$. Glutathione content was calculated from a calibration curve made with GSSG.

B.

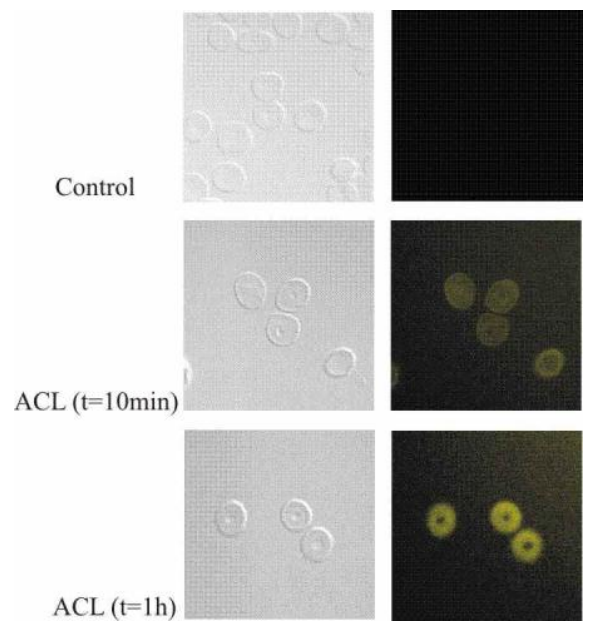

Fig. 3. Rate of aclarubicin uptake into erythrocyte (A) and pictures of human erythrocytes incubated with ACL (B). Left side: cross light. Right side: fluorescence filter. Pictures were taken with Leica DM6000B microscope. 


\section{RESULTS}

\section{ACL uptake into erythrocytes}

As shown in Fig. 3A, aclarubicin rapidly diffuses into erythrocytes. The uptake rate reaches equilibrium in about $40 \mathrm{~min}$. At the same time, ACL content in the supernatant decreases by about $45 \%$. The total amount of transported drug was estimated at $50 \%$. These results were confirmed by microscopic pictures taken after 10 and 60 minutes of incubation of erythrocytes with ACL, taking advantage of the fluorescent properties of ACL. The images clearly reveal the differences in the amount of drug transferred into erythrocytes (Fig. 3B). After 10 minutes of incubation, intensive fluorescence was visible in the peripheral parts of cells, while 50 minutes later it spread across entire erythroplasm. Control pictures reveal cell fluorescence without ACL.

A.

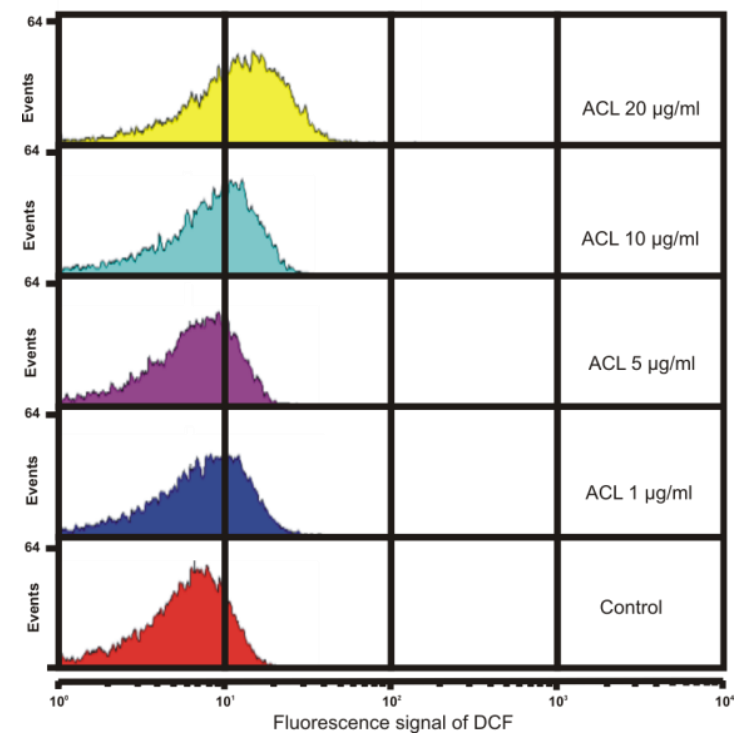

B.

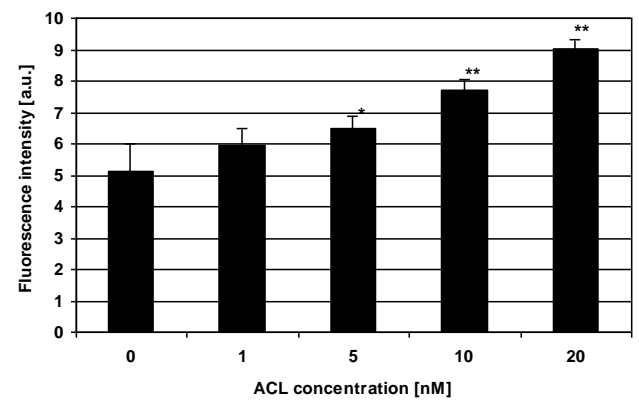

Fig.4. The effect of aclarubicin on ROS level in human erythrocytes. Cytometric histograms (A) and quantitative changes (B).* $(\mathrm{p}<0,05), * *(\mathrm{p}<0,01)$ The significance level of differences between the samples incubated with ACL in comparison to the control cells.
ROS level

The influence of aclarubicin on ROS production in human erythrocytes is shown in Fig. 4. ROS levels in red blood cells were measured with DCF fluorescence probe. The results of cytometric measurements are presented in the form of histograms (Fig. 4A) and quantitative results (Fig. 4B). The visible right shift of the main peak correlated with a rising ACL concentration indicates increased fluorescence intensity, which testifies to high levels of ROS generation. For the lowest concentration of ACL ( $1 \mathrm{nM})$, a $20 \%$ increase was observed in comparison to control, while its highest concentration $(20 \mathrm{nM})$ triggered a $77 \%$ rise. All the differences were statistically significant.

\section{Catalase activity}

Fig. 5 shows a decrease in catalase activity after treatment with increased concentrations of administered ACL. For the lowest drug concentration, a 7\% drop in the enzyme activity was indicated. For the highest concentration the catalase activity was $57.75 \mu \mathrm{mol} / \mathrm{min} / \mathrm{mgHb}$. Against the control value $(74.86 \mu \mathrm{mol} / \mathrm{min} / \mathrm{mgHb})$, this means a $23 \%$ decline. Statistically significant differences were observed across the entire concentration range.

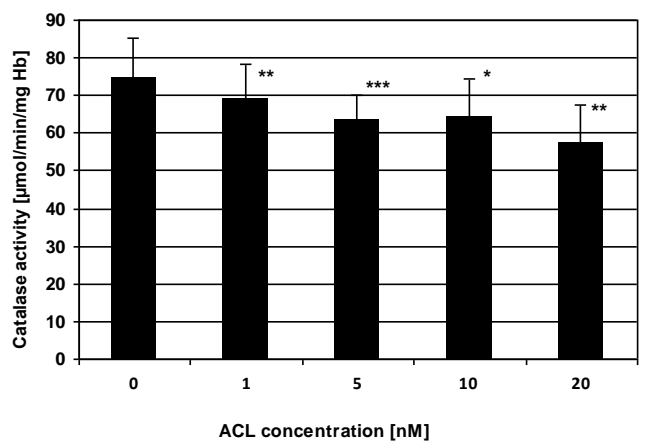

Fig.5. Catalase activity in ACL incubated erythrocytes. * $(\mathrm{p}<0,05) ; * *(\mathrm{p}<0,01) ; * * *(\mathrm{p}<0,005)$ The significance level of differences between the samples incubated with ACL in comparison to the control cells.

\section{Methemoglobin content}

The influence of ACL on intracellular methemoglobin content in human erythrocytes is presented in Fig. 6. Methemoglobin content in the investigated cells increases after treatment with ACL. With reference to controls, the results obtained for the tested concentration range were statistically significant. Given the control value of $2.2 \%$, incubation with the lowest drug concentration of $1 \mathrm{nM}$ caused an increase in metHb content by 1.5 percentage points. The highest percentage of metHb was found to be nearly $6 \%$ for the concentration of $20 \mathrm{nM}$. 


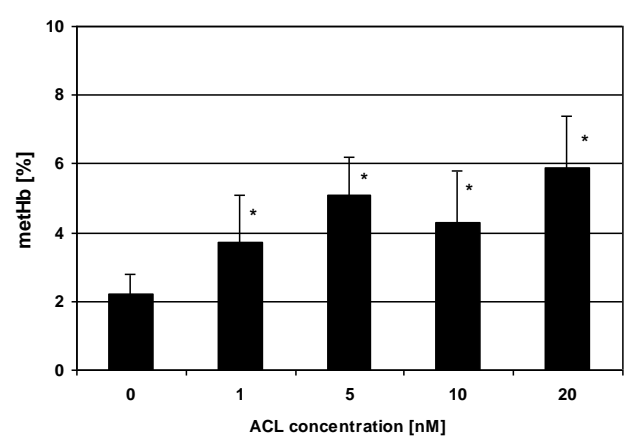

Fig. 6 Methemoglobin content in human erythrocytes incubated with ACL. * ( $<<0,05) ; * * \mathrm{p}<0,01) ; * * *(\mathrm{p}<0,005)$ The significance level of differences between the samples incubated with ACL in comparison to the control cells

\section{Reduced and total glutathione measurement}

Changes in intracellular GSH and total glutathione are shown in Table 1. GSH $(1.1 \pm 0.22 \mathrm{mmol} / \mathrm{l})$ was the predominant form of total glutathione $(1.12 \pm 0.28$ $\mathrm{mmol} / \mathrm{l})$ in control erythrocytes. The difference between total and reduced glutathione was only about $2 \%$. The incubation of erythrocytes with various doses of ACL (1-20 nM) induced no significant changes in reduced or total glutathione levels.

Table 1. The effect of aclarubicin on the reduced and total glutathione content

\begin{tabular}{ccc}
\hline $\begin{array}{c}\text { ACL } \\
{[\mathbf{n M}]}\end{array}$ & GSH [mmol/I] & $\begin{array}{c}\text { Total glutathione } \\
\text { [ mmol/l] }\end{array}$ \\
\hline 0 & $1,10 \pm 0,22$ & $1,12 \pm 0,28$ \\
1 & $1,00 \pm 0,38$ & $1,10 \pm 0,33$ \\
5 & $0,98 \pm 0,39$ & $1,08 \pm 0,25$ \\
10 & $0,95 \pm 0,35$ & $1,15 \pm 0,31$ \\
20 & $0,93 \pm 0,28$ & $1,01 \pm 0,29$ \\
\hline
\end{tabular}

\section{DISCUSSION}

In physiological conditions, normal cells produce small amounts of ROS (Gałecka, Jacewicz, Mrowicka, Florkowski \& Gałecki 2008). These molecules are essential to numerous cellular processes, but increased ROS concentrations contribute to homeostasis perturbations commonly known as oxidative stress (Bartosz 2008). In the course of evolution, cells have generated a control system to maintain ROS levels at an equilibrium. Cellular antioxidants include proteins catalyzing reactions eliminating ROS (e.g. catalase) and compounds that participate in reactions with oxidative factors or intermediate products of oxidation (e.g. glutathione). Particularly exposed to oxidative stress are erythrocytes, due to the high concentration of oxygen and significant amount of iron ions participating in the Fenton reaction. The generation of free radicals is one of the cytotoxic mechanisms of anthracyclines (Simunek, Stérba, Popelova, Adamcová, Hrdina \& Gersl 2009) and in this article we presented the effects of aclarubicin, the second generation of the anthracycline antibiotics on erythrocytes. Our results indicate that ACL diffuses into erythrocytes in shorter time and at higher amounts than DOX and EPI, whose transport kinetics we investigated previously (Marczak, Makowska, Witczak \& Jóźwiak 2009). Presumably, the spatial structure of ACL enables easier diffusion via the erythrocyte membrane compared to first generation anthracyclines. Flow cytometry results indicate that ACL contributes to a rise in the general pool of intracellular ROS dependent on anthracycline concentration. This effect has been confirmed in many studies concerning the influence of ACL and other anthracyclines on different cell types, including tumor cells (Rogalska, Koceva-Chyła \& Jóźwiak 2008, Marczak, Makowska, Witczak \& Jóźwiak 2009). Aclarubicin was also able to generate reactive oxygen species in K562 and HL-60 leukemia cell lines. (Richard, Morjani \& Chénais, 2002). Drug-induced ROS can damage the structure of proteins and impair their biological functions through oxidation of thiol groups and reacting with metal ions at enzyme active sites. In our studies the decrease of catalase activity was observed under the influence of ACL. Also other studies indicated that catalase activity was significantly decreased by treatment the K562 cells with $20 \mathrm{nM}$ ACL or $40 \mathrm{nM}$ DOX (Chenais, Andriollo, Guiraud, Belhoussine \& Jeannesson 2000). Amino acid residues and prosthetic groups undergo modifications that can result in the aggregation or fragmentation of catalase. Especially tyrosine and arginine residues located at the reactive sites of catalase are particularly sensitive to oxidative damage (Bartosz 2008).

In this study, a rising tendency in metHb content for higher drug concentrations was observed. In red blood cells a much greater content of oxyhemoglobin (oxyHb) and only a small fraction of hemoglobin in metHb form are noted (Bartosz 2008). After incubation erythrocytes with ACL the shift of this equilibrium towards the metHb form was observed. The above alterations would imply that the drug may oxidize hem-located iron. Studies performed by Shinohara \& Tanaka (1980) indicated that DOX has been shown to produce ROS and oxidize $\mathrm{Hb}$. Recent investigations indicate that anthracyclines may also directly bind to hemoglobin. The thermodynamic results revealed that hydrophobic, hydrogen bonding and electrostatic interactions played a major role in stabilizing the complex (Khan \& Khan, 2008; Khan, Islam, Yennamalli, Zia, Subbarao \& Khan, 2008).

Comparing the catalase activity with increasing metHb content for human erythrocytes incubated with the drug, some relation could be indicated. The increase in metHb content was connected with decreased catalase activity. 
Other authors observed that formation of metHb in erythrocytes exposed to $\mathrm{H}_{2} \mathrm{O}_{2}$ correlated with impaired catalase activity (Ścibior \& Czeczot 2006). Interestingly, the widespread belief that there is an exact correlation between ACL-generated rises is ROS and decreased catalase activity is unfounded. This correlation is partly explored in the current study. It may be related to the pseudoperoxidase properties of oxyhemoglobin. Hydrogen peroxide can be decomposed by oxyHb and metHb (Fedeli, Tiano, Gabbianelli, Caulini, Woźniak \& Falcioni 2001). The reaction of $\mathrm{H}_{2} \mathrm{O}_{2}$ with oxyHb contributes to the oxidation of hem-located $\mathrm{Fe}^{2+}$ to $\mathrm{Fe}^{4+}$ and the protein becomes transformed into the ferrylHb form (Gunther 2004). The reaction between metHb and hydrogen peroxide is similar to a typical catalase reaction, but proceeds at a much slower rate (Bukowska, Chajdys, Duda \& Duchnowicz 2000). The above hypothesis could explain the slightly lower catalase activity in spite of the significantly higher ROS levels. Results for GSH and GSSG concentration indicate a marginal upward tendency, although the differences are not statistically significant. This can be related to the high initial GSH concentration in erythrocytes. The fact that considerable changes in intracellular GSH concentration were not observed can be attributed to the short time of erythrocyte exposure to the drug. Presumably, in the applied time of erythrocyte incubation, instant glutathione disulfide (GSSG) regeneration could ensue. On the other hand, it is likely that during a longer exposure of these cells to ACL treatment, the activity of glutathione reductase could be significantly decreased and $\mathrm{NADP}^{+}$to NADPH reductive enzymes as well. Zatorska \& Jóźwiak (2002) conducted measurements of glutathione reductase activity in normal and Down syndrome fibroblasts exposed to DNR. A statistically significant decrease in the activity of the analyzed enzymes in comparison to controls was not revealed in normal fibroblast cells until $48 \mathrm{~h}$ of incubation.

In conclusion we can say that the presented results confirm important role of ROS in ACL cytotoxic activity.

\section{REFERENCES}

Aebi H. (1984) Catalase in vitro. Methods Enzymol. 105: 121126.

Akerboom, T.P.M., Sies, H., 1981. Assay of glutathione, glutathione disulfide and glutathione mixed disulfides in biological samples. Methods Enzymol. 77: 373-382.

Bartosz G.: Druga Twarz Tlenu. Wolne Rodniki w Przyrodzie. Wydawnictwo Naukowe PWN, Warszawa 2008

Bukowska B., Chajdys A., Duda W. \& Duchnowicz P. (2000) Catalase activity in human erythrocytes: effect of phenoxyherbicides and their metabolites. Cell Biol. Int. 24: 10: 705-711.
Chenais B., Andriollo M., Guiraud P., Belhoussine R. \& Jeannesson P. (2000) Oxidative stress involvement in chemically induced differentiation of K562 cells. Free Radical Biol. Med. 28: 18-27.

Chmiel A. \& Grudziński S. (1998) Biotechnologia i Chemia Antybiotyków. Wydawnictwo Naukowe PWN, Warszawa 1998

Dudka J. (2006) Rola reaktywnych form tlenu i azotu w zaburzeniach komórkowej homeostazy wapnia i żelaza w kardiotoksyczności antracyklinowej. Post. Hig. Med. Dośw. (online) 60: 241-247.

Ellman G. (1959) Tissue sulphydryl groups. Arch. Biochem. Biophys. 32: 70-77.

Fedeli D., Tiano L., Gabbianelli R., Caulini G.C., Woźniak M. \& Falcioni G. (2001) Hemoglobin components from trout (Salmo irideus); determination of their peroxidative activity. Comp. Biochem. Physiol. Part B 130: 559-564.

Gałecka E., Jacewicz R., Mrowicka M., Florkowski A. \& Gałecki P. (2008) Enzymy antyoksydacyjne - budowa, właściwości, funkcje. Pol. Merk. Lek. 147: 266.

Grasso S., Scifo C., Cardile V., Gulino R. \& Renis M. (2003) Adaptive response to the stress induced by hyperthermia or hydrogen peroxide in human fibroblasts. Exp. Biol. Med. 228: 491-498.

Gunther M.R. (2004) Probing the free radicals formed in the metmyoglobin-hydrogen peroxide reaction. Free Rad. Biol. Med. 36: 1345-1354.

Hajji N., Mateos S., Pastor N., Dominguez I. \& Cortem F. (2005) Induction of genotoxic and cytotoxic damage by aclarubicin, a dual topoisomerase. Mutat. Res. 583: 26-35.

Kania K., Zych A. \& Jóźwiak Z. (2007) Involvement of reactive oxygen species in aclarubicin-induced death of human trisomic and diabetic fibroblasts. Toxicol. in Vitro 21: 1010-1019.

Khan S.N., Islam B., Yennamalli R., Zia Q., Subbarao N. \& Khan A.U. (2008) Characterization of doxorubicin binding site and drug induced alteration in the functionally important structural state of oxyhemoglobin. J. Pharmaceutics Biomed. Anal 48: 1096-1104

Khan S.N \& Khan A.U. (2008) An in silico approach to map the binding site of doxorubicin on hemoglobin. Bioinformation 2: 401-404.

Kłyszejko-Stefanowicz L: Ćwiczenia z biochemii. Wydawnictwo Naukowe PWN, Warszawa 2003

Łubgan D., Marczak A., Walczak M., Distel L. \& Jóźwiak Z. (2006) Mechanizmy działania doksorubicyny (DOX) obecny stan wiedzy. Przeglad Lek. 63(9): 782-788.

Marczak A., Makowska K., Witczak P. \& Jóźwiak Z. (2009) Porównanie wpływu doksorubicyny i epirubicyny na wybrane parametry erytrocytów człowieka. Problemy Ter. Monit. 20: 175-186.

Oliński R. \& Jurgowiak M. (1999) Rola reaktywnych form tlenu w procesach mutagenezy i karcynogenezy. Post. Biochem. 45: 50-58.

Richard D., Hollender P. \& Chénais B. (2002) Involvement of reactive oxygen species in aclarubicin-induced differentiation and invasiveness of HL-60 leukemia cells. Int. J. Oncol. 21: 393-399.

Richard D., Morjani H. \& Chenias B. (2002) Free radical production and labile iron pool decrease triggered by subtoxic concentration of aclarubicin in human leukemia cell lines. Leuk. Res. 26: 927-931. 
Rogalska A., Koceva-Chyła A. \& Jóźwiak Z. (2008) Aclarubicin-induced ROS generation and collapse of mitochondrial membrane potential in human cancer cell lines. Chem. Biol. Interact. 176: 58-70.

Rogalska A., Marczak A. \& Jóźwiak Z. (2008) Aklarubicyna alternatywa dla komórek opornych na antracykliny I generacji. Post. Biol. Kom. 1: 97-111.

Shinohara K \& Tanaka KR (1980) The effects of adriamycin (doxorubicin $\mathrm{HCl}$ ) on human red blood cells. Hemoglobin 4: 735-745.

Simunek T, Stérba M, Popelova O, Adamcová M, Hrdina R \& Gersl V. (2009) Anthracycline-induced cardiotoxicity: overview of studies examining the roles of oxidative stress and free cellular iron. Pharmacol. Rep. 61: 154-171

Szuławska A. \& Czyż M. (2006) Molekularne mechanizmy działania antracyklin. Post. Hig. Med. Dośw. (online) 60: 78-100.

Ścibior D. \& Czeczot H. (2006) Katalaza - budowa, właściwości, funkcje. Post. Hig. Med. Dośw. (online) 60: 170-180.

Zatorska A. \& Jóźwiak Z. (2002) Involvement of glutathione and glutathione-related enzymes in the protection of normal and trisomic human fibroblasts against daunorubicin. Cell Biol. Int. 26: 383-391.

Zweier J.L., Gianni L., Muindi J. \& Myers C.E. (1986) Differences in $\mathrm{O} 2$ reduction by the iron complexes of adriamycin and daunomycin: the importance of the sidechain hydroxyl group. Biochim. Biophys. Acta 884: 326336. 